\title{
Gender Differences in Body Mass Index, Body Weight Perception, weight satisfaction, disordered eating and Weight control strategies among Indian Medical and Nursing Undergraduates
}

\author{
Poreddi Vijayalakshmi ${ }^{1}$ \\ Rohini Thimmaiah ${ }^{2}$ \\ S. Sai Nikhil Reddy ${ }^{3}$ \\ Kathyayani B.V ${ }^{4}$ \\ Sailaxmi Gandhi ${ }^{5}$ \\ Suresh BadaMath ${ }^{6}$
}

\section{Gender Differences in Body Mass Index, Body Weight Perception, weight satisfaction, disordered eating and Weight control strategies among Indian Medical and Nursing Undergraduates}

Objective. To assess gender disparity in body weight perception, Body Mass Index (BMI), weight satisfaction and role of depression among undergraduate Medical and Nursing students. Methods. A descriptive cross sectional descriptive study was conducted in conveniently selected medical $(n=241)$ and nursing ( $n=213)$ students of Bangalore, South India.
Data was collected using self-administered SCOFF questionnaires. Results. Our findings revealed that men had a significantly higher BMI than women $(t=5.403$, $p<0.001$ ). More number of women compared to men, perceived themselves as over weight $(74.8 \%)$ and not satisfied with their weight status (81.6\%). More men than women scored positively for disordered eating behaviors on SCOFF ( $45.4 \%$ vs. $31.1 \%$ ) and EAT scale $(16.5 \%$ vs. $8.7 \%)$. While, $48.2 \%$ of the women practice binge eating, $41.2 \%$ of the men practice it $(p<0.004)$; more men $(47.4 \%)$ than women $(25.4 \%)$ exercised for more than sixty minutes $(p<0.001)$ to control their weight. Conclusion. Findings indicate

1 RN, RM, BSN, MSN. College of Nursing, National Institute of Mental Health and Neuro Sciences, (Institute of National Importance), Bangalore (India).email: pvijayalakshmireddy@gmail.com

2 MD. Toowoomba Base Hospital, Toowoomba, Queensland (Australia). email: drrohinimd@gmail.com

3 Second year MBBS. Bangalore Medical College and Research Institute, Bangalore (India). email: saithereddy@gmail. com

4 RN, Ph.D. Professor, College of Nursing. National Institute of Mental Health and Neuro Sciences, (Institute of National Importance), Bangalore (India). email: bv.kathyayani@rediffmail.com

5 Ph.D. Additional Professor, Department of Nursing National Institute of Mental Health and Neuro Sciences, (Institute of National Importance), Bangalore (India). email: sailaxmi63@yahoo.com

6 MD, Psychiatry. Professor, Department of Psychiatry National Institute of Mental Health and Neuro Sciences, (Institute of National Importance), Bangalore (India). email: nimhans@gmail.com

Conflicts of interest: none.

Received: March 7th 2017.

Acepted: July 10th 2017.

How to cite this article: Vijayalakshmi P, Thimmaiah R, Reddy SSN, Kathyayani BV, Gandhi S, Math SB. Gender Differences in Body Mass Index, Body Weight Perception, weight satisfaction, disordered eating and Weight control strategies among Indian Medical and Nursing Undergraduates. Invest. Educ. Enferm. 2017; 35(3):276-284

DOI: 10.17533/udea.iee.v35n3a04 
Gender Differences in Body Mass Index, Body Weight Perception, weight satisfaction, disordered eating and Weight control strategies among Indian Medical and Nursing Undergraduates

small differences between the genders that have to be taken in consideration in planning interventional programs to prevent eating disorders in this population.

Descriptors: body mass index; weight perception; cross-sectional studies; students, nursing; students, medical; feeding and eating disorders.

\section{Diferencias por sexo en el índice de masa corporal, percepción del peso corporal, satisfacción con el peso, desórdenes de la alimentación y estrategias para el control de peso en estudiantes de medicina $y$ enfermería de la India}

Objetivo. Evaluar la disparidad por sexo en el índice de masa corporal, la percepción del peso corporal, la satisfacción con el peso, los desórdenes de la alimentación y estrategias para el control de peso en estudiantes de medicina y enfermería de la India. Métodos. Se realizó un estudio descriptivo de corte transversal con una muestra tomada a conveniencia de estudiantes de Medicina $(n=241)$ y de Enfermería $(n=213)$ de Bangalore, en el sur de India. Los datos se recolectaron usando los instrumentos autoadministrados SCOFF y EAT-26. Resultados. Los hombres tenían un IMC significativamente mayor que las mujeres $(t=5.403, p<0.001)$; un mayor porcentaje de mujeres, en comparación con los hombres, percibía que pesaba más $(74.8 \%)$, sin embargo, no estaban satisfechas con su peso (81.6\%). Los hombres y las mujeres tuvieron puntajes que mostraban riesgo de tener trastornos de conductas alimentarias en el SCOFF (45.4\% vs. $31.1 \%$ ) y en el EAT $(16.5 \%$ vs. $8.7 \%$ ). Mientras que el $48.2 \%$ de las mujeres practicaba el atracón, el $41.2 \%$ de los hombres lo tenía $(p<0.004)$; más hombres $(47.4 \%)$ que mujeres $(25.4 \%)$ se ejercitaban por más de sesenta minutos $(p<0.001)$ para controlar su peso. Conclusión. Los hallazgos indican pequeñas diferencias por sexo que deben ser tenidas en cuenta en la planeación de programas de intervención para prevenir los trastornos en la alimentación en esta población.

\section{Introduction}

Prevalence of eating disorders has become growing concern among college students in India. Eating disorders are the common psychiatric illnesses
Descriptores: índice de masa corporal; percepción del peso; estudios transversales; estudiantes de enfermería; estudiantes de medicina; trastornos de alimentación y de la ingestión de alimentos.

\section{Diferenças por sexo no índice de massa corporal, percepção do peso corporal, satisfação com o peso, desordens da alimentação e estratégias para o controle de peso em estudantes de medicina e enfermagem da Índia}

Objetivo. Avaliar a disparidade por sexo no índice de massa corporal, percepção do peso corporal, satisfação com o peso, desordens da alimentação e estratégias para o controle de peso em estudantes de medicina e enfermagem da Índia. Métodos. Se realizou um estudo descritivo de corte transversal com uma amostra tomada a conveniência de estudantes de Medicina $(n=241)$ e de Enfermagem $(n=213)$ de Bangalore, no sul da Índia. Os dados foram coletados usando os instrumentos auto-administrados SCOFF e EAT-26. Resultados. Os homens tinham um IMC significativamente maior que as mulheres $(t=5.403, p<0.001)$, mas um maior número de mulheres em comparação com os homens, percebiam que pesavam mais (74.8\%) e não estavam satisfeitas com seu peso (81.6\%). Os homens e as mulheres tiveram pontuações que mostravam risco de ter transtornos de condutas alimentar no SCOFF $(45.4 \%$ vs. $31.1 \%$ ) e no EAT ( $16.5 \%$ vs. $8.7 \%$ ). Enquanto que $48.2 \%$ das mulheres praticavam o excesso, já os homens $41.2 \%$ ( $p<0.004)$; mais homens $(47.4 \%)$ do que mulheres $(25.4 \%)$ se exercitavam por mais de sessenta minutos $(p<0.001)$ para controlar seu peso. Conclusão. As descobertas indicam pequenas diferenças por sexo que devem ser tidas em conta no planejamento de programas de intervenção para prevenir os transtornos na alimentação nesta população.

Descritores: índice de massa corporal; percepção de peso; estudos transversais; estudantes de enfermagem; estudantes de medicina; transtornos da alimentação e da ingestão de alimentos.

with a persistent disturbance in eating patterns or other behaviors intended to control weight, body size or shape. ${ }^{(1)}$ Eating disorders also affect physical and nutritional health, psychological functioning and if untreated, they can be fatal. ${ }^{(2)}$ Earlier studies 
have shown that eating disorders have the highest mortality rate of any mental illness. ${ }^{(3)}$ According to DSM-5, the types of eating disorders are Anorexia Nervosa, Bulimia Nervosa, Binge Eating Disorder, Pica, Rumination Disorder, Avoidant/Restrictive Food Intake Disorder (ARFID), Other Specified Feeding or Eating Disorder (OSFED). ${ }^{(4)}$

Epidemiological studies have shown that anorexia nervosa (AN) and bulimia nervosa (BN) are more common among females than males. ${ }^{(5)}$ Generally, it is believed that body weight and its perception play an important role in the physical and mental well-being of a person. ${ }^{(6)}$ Widely published literature indicates gender differences in relation to body weight perception, weight dissatisfaction and disordered eating behaviors. ${ }^{(7)}$ Though, both women and men suffer from eating disorders, men with eating disorders have been overlooked, understudied, and underreported. ${ }^{(8)}$

Published research report that young academics in the area of health such as nutrition, physical education, nursing and medicine were high risk for Eating Disorders. ${ }^{(9)}$ Further, in a survey it was revealed that two-thirds of psychiatrists had seen at least one case of ED, indicating that EDs are not uncommon in urban India. ${ }^{(10)}$ In India, research on issues related to EDS mainly focused either among adolescents or female university students are well documented. ${ }^{(11)}$ However, there is dearth of literature available among health science students. ${ }^{(12)}$ In addition, there are no studies that examined gender differences related to eating behaviors from India. Thus, the present study was aimed to assess gender differences in Body Mass Index, body weight perception, weight satisfaction, disordered eating and weight control strategies among Indian Medical and Nursing Undergraduates

\section{Methods}

This study was carried out among medical and nursing undergraduates from renowned colleges from Bangalore, South India between August to October 2014. This was a descriptive cross sectional study conducted among conveniently selected sample.
The study criteria include students those were enrolled in to medical and nursing undergraduate courses. Students those were diagnosed to be having psychiatric illnesses and below 18 years were excluded from the study. There were 494 individuals were eligible to participate in to the study. The students who had not volunteered (refused consent) $(n=12)$, absent during data collection period $(n=18)$ and incomplete questionnaires $(n=10)$ were excluded out from the study's population. Hence, the final sample for the present study comprised of 454 undergraduate medical $(n=241)$ and nursing ( $n=213$ ) students with high response rate $(91.9 \%)$.

\section{Definitions}

In the present study, eating attitudes include thoughts, beliefs, feelings, behaviors and relationship with food. ${ }^{(13)}$ Body weight perception refers to the personal evaluation of one's weight as "underweight" or "normal weight" or "overweight" irrespective of actual body mass index ${ }^{(14)}$ Body Mass Index (BMI) in this study was calculated based on self-reported height and weight. The BMI was calculated by dividing body weight in kilograms by the square of height in meters and BMI classification was according to Asian population by the WHO (2004). A BMI $\geq 27.50$ indicates a higher risk for obesity, a $\mathrm{BMI}=23.00$ -27.50 an increased risk of being overweight, a $\mathrm{BMI}=18.50-23.00$ defines the normal range, and a BMI of less than 18.50 is considered as underweight.

\section{Measures}

Socio-Demographic Questionnaire. This questionnaire collected socio-demographic variables regarding participants' back ground information i.e. age, gender, education, year of education, religion, background, current weight, height, weight satisfaction( with three responses, 'satisfied', 'not satisfied', 'not sure'), and weight perception (with three responses 'underweight', 'normal weight', 'over weight'). ${ }^{(6)}$

SCOFF questionnaire. The SCOFF (Sick, Control, One, Fat, Food) questionnaire developed by Morgan et al. ${ }^{(15)}$ It is a short and simple screening 
Gender Differences in Body Mass Index, Body Weight Perception, weight satisfaction, disordered eating and Weight control strategies among Indian Medical and Nursing Undergraduates

tool for eating disorders with five items. Every 'yes' answer to a question is equivalent to one point. A score of two or more points indicates the patient may be suffering from an eating disorder. This is a highly effective in screening tool for suspicion of eating disorders with good psychometric properties (kappa statistic $=0.73$ to 0.82$){ }^{(16)}$

Eating Attitudes Test $\mathbf{- 2 6}$. The Eating Attitude Test-26 (EAT-26) is a self- reported questionnaire widely used to identify the presence of any eating disorder. ${ }^{(17)}$ This scale has two sections. Section A consists of 26 items to assess eating attitudes with three subscales namely; Dieting (13 items$1,6,7,10,11,12,14,16,17,22,23,24,26)$, Bulim ia \& Food Preoccupation ( 6 items-3,4,9,18,21,25) and Oral control (7 items-2,5,8,13,15,19,20). Options for the responses are in four-point Likertscale $(3$ = always, 2 = usually, $1=$ often, 0 $=$ sometimes/rarely/never), where higher scores indicating a higher likelihood of maladaptive eating attitudes and behaviors. The total sum of EAT-26 scores ranges from 0 to 78 . A score of 20 or above is regarded as at risk of eating disorders and diagnostic follow-ups are required. ${ }^{(18)}$ Section B consisted of six items to assess various aspects of distorted eating behavior, including bulimic tendencies, body image perception and degree of willful control over eating behavior.

Patient Health Questionnaire. The PHQ-9 is a self-reported, nine-item questionnaire specific to depression with good psychometric properties. ${ }^{(19)}$ This is a four-point Likert-scale $(0=$ not at all, $1=$ several days, 2 =more than half the days, or $3=$ nearly every day) with score range 0-27 ( 0 indicating no depressive symptoms and 27 indicating all symptoms occurring nearly daily). The score $<4$ indicates minor depression, 5-14 suggests moderate depression and $>14$ indicates severe depression.

\section{Data collection procedure}

After obtaining permission from college administrators, the participants were approached by the primary author after their regular lectures. The students were informed about the aims of the research. After acquiring verbal consent from the participants, English versions of the questionnaires were administered. The students took approximately 15-20 minutes to complete the questionnaires.

\section{Ethical considerations}

The study protocol was approved by Institute Ethics committee. Permission was sought from the administrators of the colleges where the study was conducted. The participants were explained that participation in to the study is purely voluntary and their responses would have no influence on their semester exams. Data collection tools contained no identifying information and therefore kept the individual responses confidential.

\section{Data Analysis}

The data were analyzed using appropriate statistics and results were presented in narratives and tables. Descriptive (frequency, percentage, mean and standard deviation) and inferential statistics (Chi-square test, t- test) was used to interpret the data. The results considered statistically significance if the $p$ value is less than 0.05 .

\section{Results}

The present study comprised of 454 individuals of whom majority $(n=357,78.6 \%)$ were females. The mean age for the men was $20 \mathrm{yrs}(S D=2.04)$ and for the women was $19 \mathrm{yrs}(S D=1.32)$. Men $(\mathrm{M} \pm \mathrm{SD}, 23.06 \pm 4.34)$ had a significantly higher $B M I$ than women $(M \pm S D, 23.06 \pm 4.34, t=5.403$, $\mathrm{p}<0.001$ ). Table 1 shows that, women in relation to men were younger $(71.7 \%$ vs. $58.8 \%$ ), nursing students $(58.3 \%$ vs. $5.2 \%)$, with rural back ground $(30.5 \%$ vs. $15.5 \%)$ and have less Weight status according to BMI of overweight $(20.7 \%$ vs. $47.4 \%$ ); these differences were statistically significant. The self-perception of overweight was very similar in both genders $(28.9 \%$ in men and $23.2 \%$ in women) as well as the non-satisfaction with the weight $(33 \%$ in men and $39.8 \%$ in women). 
Table 1. Characteristics of the participants

\begin{tabular}{|c|c|c|c|c|c|c|c|c|c|}
\hline \multirow{3}{*}{ Variable } & \multirow{3}{*}{ Group } & \multicolumn{7}{|c|}{ Gender } & \multirow{3}{*}{$p$ value } \\
\hline & & \multicolumn{2}{|c|}{$\begin{array}{c}\text { Men } \\
(n=97)\end{array}$} & \multicolumn{2}{|c|}{$\begin{array}{c}\text { Women } \\
(n=357)\end{array}$} & \multicolumn{2}{|c|}{$\begin{array}{c}\text { Total } \\
(n=454)\end{array}$} & \multirow[t]{2}{*}{$\begin{array}{c}x^{2} \\
\text { value }\end{array}$} & \\
\hline & & $n$ & $\%$ & $n$ & $\%$ & $n$ & $\%$ & & \\
\hline Age & $\begin{array}{l}18-20 y r s \\
21-23 y r s \\
>23 y r s\end{array}$ & $\begin{array}{c}57 \\
34 \\
6\end{array}$ & $\begin{array}{c}58.8 \\
35.1 \\
6.2\end{array}$ & $\begin{array}{c}256 \\
101 \\
0\end{array}$ & $\begin{array}{l}71.7 \\
28.3 \\
0.0\end{array}$ & $\begin{array}{c}313 \\
135 \\
6\end{array}$ & $\begin{array}{c}68.9 \\
29.7 \\
1.3\end{array}$ & 25.109 & 0.001 \\
\hline Education & $\begin{array}{l}\text { Medicine } \\
\text { Nursing }\end{array}$ & $\begin{array}{c}92 \\
5\end{array}$ & $\begin{array}{c}94.8 \\
5.2\end{array}$ & $\begin{array}{l}149 \\
208\end{array}$ & $\begin{array}{l}41.7 \\
58.3\end{array}$ & $\begin{array}{l}241 \\
213\end{array}$ & $\begin{array}{l}53.1 \\
46.9\end{array}$ & 86.383 & 0.001 \\
\hline Back ground & $\begin{array}{l}\text { Rural } \\
\text { Semi-urban } \\
\text { Urban }\end{array}$ & $\begin{array}{l}15 \\
24 \\
58\end{array}$ & $\begin{array}{l}15.5 \\
24.7 \\
59.8\end{array}$ & $\begin{array}{c}109 \\
91 \\
157\end{array}$ & $\begin{array}{l}30.5 \\
25.5 \\
44.0\end{array}$ & $\begin{array}{l}124 \\
115 \\
157\end{array}$ & $\begin{array}{l}27.3 \\
25.3 \\
47.4\end{array}$ & 10.387 & 0.006 \\
\hline $\begin{array}{l}\text { Weight status } \\
\text { according to BMI }\end{array}$ & $\begin{array}{l}\text { Underweight } \\
\text { Normal weight } \\
\text { Overweight }\end{array}$ & $\begin{array}{l}13 \\
38 \\
46\end{array}$ & $\begin{array}{l}13.4 \\
39.2 \\
47.4\end{array}$ & $\begin{array}{l}101 \\
182 \\
74\end{array}$ & $\begin{array}{l}28.3 \\
51.0 \\
20.7\end{array}$ & $\begin{array}{l}114 \\
220 \\
120\end{array}$ & $\begin{array}{l}25.1 \\
48.5 \\
26.4\end{array}$ & 29.491 & 0.001 \\
\hline $\begin{array}{l}\text { Perception of } \\
\text { weight }\end{array}$ & $\begin{array}{l}\text { Underweight } \\
\text { Normal weight } \\
\text { Overweight }\end{array}$ & $\begin{array}{l}18 \\
51 \\
28\end{array}$ & $\begin{array}{l}18.6 \\
52.6 \\
28.9\end{array}$ & $\begin{array}{c}65 \\
209 \\
83\end{array}$ & $\begin{array}{l}18.2 \\
58.5 \\
23.2\end{array}$ & $\begin{array}{c}83 \\
260 \\
111\end{array}$ & $\begin{array}{l}18.3 \\
57.3 \\
24.4\end{array}$ & 1.463 & 0.481 \\
\hline $\begin{array}{l}\text { Satisfaction of } \\
\text { weight }\end{array}$ & $\begin{array}{l}\text { Satisfied } \\
\text { Not satisfied } \\
\text { Unsure }\end{array}$ & $\begin{array}{c}60 \\
32 \\
5\end{array}$ & $\begin{array}{c}61.9 \\
33.0 \\
5.2\end{array}$ & $\begin{array}{c}192 \\
142 \\
23\end{array}$ & $\begin{array}{c}53.8 \\
39.8 \\
6.4\end{array}$ & $\begin{array}{l}252 \\
174 \\
28\end{array}$ & $\begin{array}{c}55.5 \\
38.3 \\
6.2\end{array}$ & 2.018 & 0.365 \\
\hline
\end{tabular}

Table 2 shows association between gender and SCOFF, EAT scores. More men than women scored positively for disordered eating behaviors on SCOFF scale (45.4\% vs. $31.1 \%$ ) and for problematic behavior on EAT scale (16.5\% vs. $8.7 \%$ ). Severe depression in men was the double than in women ( $9.3 \%$ vs. $4.5 \%$ ), but this difference was no significant.
With regard to weight control behaviors, more number of women (48.2\%) than men (41.2\%) practice binge eating and this difference was statistically significant. Most of the men and women disagreed that they made themselves sick by vomiting ( $91.8 \%$ and $93.8 \%$ respectively) and used laxatives, diet pills or diuretics to control their weight $(95.9 \%$ and $97.5 \%$ respectively).

Table 2. Association between gender and SCOFF, EAT, Depression scores

\begin{tabular}{|c|c|c|c|c|c|c|c|c|c|}
\hline \multirow{3}{*}{ Variable } & \multirow{3}{*}{ Group } & \multicolumn{6}{|c|}{ Gender } & \multirow[t]{3}{*}{$x^{2}$ value } & \multirow[t]{3}{*}{$p$ value } \\
\hline & & \multicolumn{2}{|c|}{ Men } & \multicolumn{2}{|c|}{ Women } & \multicolumn{2}{|c|}{ Total } & & \\
\hline & & $n$ & $\%$ & $n$ & $\%$ & $n$ & $\%$ & & \\
\hline Scoff scores & $\begin{array}{l}\text { Negative }<2 \\
\text { Positive }>2\end{array}$ & $\begin{array}{l}53 \\
44\end{array}$ & $\begin{array}{l}54.6 \\
45.4\end{array}$ & $\begin{array}{l}246 \\
111\end{array}$ & $\begin{array}{l}68.9 \\
31.1\end{array}$ & $\begin{array}{l}299 \\
155\end{array}$ & $\begin{array}{l}65.9 \\
34.1\end{array}$ & 6.906 & 0.009 \\
\hline EAT Scores & $\begin{array}{l}\text { Non-problematic behaviors }<20 \\
\text { Problematic behavior }>20\end{array}$ & $\begin{array}{l}81 \\
16\end{array}$ & $\begin{array}{l}83.5 \\
16.5\end{array}$ & $\begin{array}{c}326 \\
31\end{array}$ & $\begin{array}{l}91.3 \\
8.7\end{array}$ & $\begin{array}{c}407 \\
47\end{array}$ & $\begin{array}{l}89.6 \\
10.4\end{array}$ & 5.015 & 0.025 \\
\hline $\begin{array}{l}\text { Depression } \\
\text { scores }\end{array}$ & $\begin{array}{l}\text { Minor depression }(<4) \\
\text { Moderate depression }(5-14) \\
\text { Severe depression }(>14)\end{array}$ & $\begin{array}{c}50 \\
38 \\
9\end{array}$ & $\begin{array}{c}51.5 \\
39.2 \\
9.3\end{array}$ & $\begin{array}{l}179 \\
162 \\
16\end{array}$ & $\begin{array}{c}50.1 \\
45.4 \\
4.5\end{array}$ & $\begin{array}{c}229 \\
200 \\
25\end{array}$ & $\begin{array}{c}50.4 \\
44.1 \\
5.5\end{array}$ & 3.883 & 0.143 \\
\hline
\end{tabular}


However, $47.4 \%$ of men compared to $25.4 \%$ of women endorsed that they have exercised more than sixty minutes $(p<0.001)$. More men $(9.3 \%)$ than women $(3.4 \%)$ lost their weight more than
$10 \mathrm{kgs}$ in the past six months and $8.2 \%$ of men and $3.6 \%$ of women agreed that they were treated for eating disorders. These differences were statistically significant. (Table 3 ).

Table 3. Gender wise weight control behaviors of the participants

\begin{tabular}{|c|c|c|c|c|c|c|c|}
\hline \multirow{3}{*}{ Variable } & \multicolumn{7}{|c|}{ Gender } \\
\hline & \multirow[t]{2}{*}{ Group } & \multicolumn{2}{|c|}{ Men } & \multicolumn{2}{|c|}{ Women } & \multirow[t]{2}{*}{$x^{2}$ value } & \multirow[t]{2}{*}{$p$ value } \\
\hline & & $n$ & $\%$ & $n$ & $\%$ & & \\
\hline Gone on eating binges & $\begin{array}{l}\text { Never } \\
\text { Once a month or less } \\
2-3 \text { times a month Once a week } \\
\text { Once a week } \\
2-6 \text { times a week } \\
\text { Once a day or more }\end{array}$ & $\begin{array}{l}57 \\
17 \\
12 \\
7 \\
4 \\
0\end{array}$ & $\begin{array}{c}58.8 \\
17.5 \\
12.4 \\
7.2 \\
4.1 \\
0\end{array}$ & $\begin{array}{l}185 \\
105 \\
28 \\
29 \\
2 \\
8\end{array}$ & $\begin{array}{l}51.8 \\
29.4 \\
7.8 \\
8.1 \\
0.6 \\
2.2\end{array}$ & 11.591 & 0.041 \\
\hline $\begin{array}{l}\text { Ever made yourself sick } \\
\text { (vomited) }\end{array}$ & $\begin{array}{l}\text { Never } \\
\text { Once a month or less } \\
2-3 \text { times a month Once a week } \\
\text { Once a week } \\
2-6 \text { times a week } \\
\text { Once a day or more }\end{array}$ & $\begin{array}{l}89 \\
5 \\
1 \\
1 \\
1 \\
0\end{array}$ & $\begin{array}{l}91.8 \\
5.2 \\
1.0 \\
1.0 \\
1.0 \\
0\end{array}$ & $\begin{array}{c}335 \\
11 \\
4 \\
4 \\
1 \\
2\end{array}$ & $\begin{array}{l}93.8 \\
3.1 \\
1.1 \\
1.1 \\
1.1 \\
0.6\end{array}$ & 2.497 & 0.777 \\
\hline $\begin{array}{l}\text { Ever used laxatives, diet } \\
\text { pills or diuretics (water } \\
\text { pills) }\end{array}$ & $\begin{array}{l}\text { Never } \\
\text { Once a month or less } \\
2-3 \text { times a month Once a week } \\
\text { Once a week } \\
2-6 \text { times a week } \\
\text { Once a day or more }\end{array}$ & $\begin{array}{l}93 \\
3 \\
1 \\
0 \\
0 \\
0\end{array}$ & $\begin{array}{l}95.9 \\
3.1 \\
1.0 \\
0 \\
0 \\
0\end{array}$ & $\begin{array}{c}348 \\
4 \\
2 \\
2 \\
1 \\
0\end{array}$ & $\begin{array}{l}97.5 \\
1.1 \\
0.6 \\
0.6 \\
0.3 \\
0\end{array}$ & 3.015 & 0.551 \\
\hline $\begin{array}{l}\text { Exercised more than } 60 \\
\text { minutes }\end{array}$ & $\begin{array}{l}\text { Never } \\
\text { Once a month or less } \\
2-3 \text { times a month Once a week } \\
\text { Once a week } \\
2-6 \text { times a week } \\
\text { Once a day or more }\end{array}$ & $\begin{array}{l}51 \\
20 \\
8 \\
2 \\
9 \\
7\end{array}$ & $\begin{array}{l}52.6 \\
20.6 \\
8.2 \\
2.1 \\
9.3 \\
7.2\end{array}$ & $\begin{array}{c}266 \\
39 \\
9 \\
11 \\
18 \\
14\end{array}$ & $\begin{array}{l}74.6 \\
10.9 \\
2.5 \\
3.1 \\
5.0 \\
3.9\end{array}$ & 21.819 & 0.001 \\
\hline $\begin{array}{l}\text { Lost } 10 \mathrm{~kg} \text { or more in } \\
\text { the past } 6 \text { months }\end{array}$ & $\begin{array}{l}\text { Yes } \\
\text { No }\end{array}$ & $\begin{array}{c}9 \\
88\end{array}$ & $\begin{array}{c}9.3 \\
90.7\end{array}$ & $\begin{array}{c}12 \\
345\end{array}$ & $\begin{array}{c}3.4 \\
96.6\end{array}$ & 6.053 & 0.014 \\
\hline $\begin{array}{l}\text { Treated for an eating } \\
\text { disorder }\end{array}$ & $\begin{array}{l}\text { Yes } \\
\text { No }\end{array}$ & $\begin{array}{c}8 \\
89\end{array}$ & $\begin{array}{l}8.2 \\
91.8\end{array}$ & $\begin{array}{c}13 \\
344\end{array}$ & $\begin{array}{l}3.6 \\
96.4\end{array}$ & 3.668 & 0.055 \\
\hline
\end{tabular}

\section{Discussion}

The present study was aimed to examine the gender differences in magnitude of eating disorders, body dissatisfaction and depression among Indian nursing and medical undergraduates. The findings indicate that more number of women than men were dissatisfied with their body weight, perceived themselves as overweight. But more number of men than women shown to be high risk for development of eating disorders on EAT and SCOFF scales. It is particularly noteworthy that $48.2 \%$ of women and $41.2 \%$ of men practiced binge eating to control their weight.

In the present study sample, mean BMI was significantly higher in men than in women. This is in consistent with earlier studies. ${ }^{(20)}$ In line with previous research, ${ }^{(21)}$ more number of women in this study was underweight. However, the number 
of women those were overweight was higher than men. These findings differ from a study that examined gender differences in body mass index (BMI), body weight perception, eating attitudes and weight loss strategies among undergraduate students in Malaysia. ${ }^{(21)}$ Earlier research indicates that female adolescents tend to perceive their body weight inaccurately when compared to BMI. (22) Similarly, in our study, approximately equal percentage $(13.1 \%)$ of men and women perceived themselves as under weight or over weight. While men underestimate their weight, women felt that they were obese. These findings also were supported by a recent study among Korean high school students. ${ }^{(23)}$ These findings indicate an urgent concern as these individuals may engage in undue weight loss practices and may put themselves at risk of nutritional deficiencies. ${ }^{(24)}$

Body weight dissatisfaction is common in many modern societies and it appears to have grown over time. ${ }^{(7)}$ Widely published literature ${ }^{(21)}$ indicates that females were more dissatisfied with their body weight than males. In a study among adult Americans found that women were around twice as likely as men to be dissatisfied with their body size. ${ }^{(25)}$ Our study findings also were in concordance with these studies as $81.6 \%$ of the women were dissatisfied with their weight compared to $18.4 \%$ of the men. However, more empirical evidence is needed in this regard to identify the gender differences in relation with body weight satisfaction.

Early published literature(26) report females are at high-risk of eating disorders as compared to males. However, our study revealed more men than women scored positively for disordered eating behaviors on SCOFF (45.4\% vs. $31.1 \%)$ and EAT scale ( $16.5 \%$ vs. $8.7 \%$ ). These findings were also comparable to a recent study among undergraduate and post graduate students found that men with overweight had greater eating disorder risk (males $\mathrm{OR}=3.5$; females $\mathrm{OR}=2.0$ ), binge eating (males $\mathrm{OR}=2.1$; females $\mathrm{OR}=1.9$ ), and use of compensatory behaviors (males

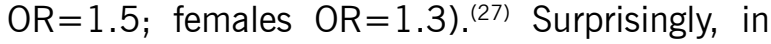
this study $9.3 \%$ of men reported severe depression compared to $5.5 \%$ in women. However, this difference was no significant. These findings indicate the need of conducting further studies to screen for depression for earlier intervention to prevent disordered eating behaviors in women.

Earlier studies report that females were generally more concerned about body weight, body shape and eating than males. They diet more frequently, had self-induced vomiting, and used laxatives and exercise as their weight-loss strategies ${ }^{(21)}$ In line with previous research, ${ }^{(28)}$ our findings also observed that nearly half of the women practice binge eating to control their weight. These findings differed from previous studies that showed no gender differences in the prevalence of binge eating. ${ }^{(20)}$ On the contrary, nearly half of the men exercised more than sixty minutes and lost weight more than $10 \mathrm{kgs}$ in the past six months. Previous studies also found similar findings. ${ }^{(29)}$ Furthermore, $8.2 \%$ of men stated that they had undergone treatment for eating disorders. These findings could be due to the stigma attached to eating disorders ${ }^{(30)}$ or women don't want to disclose about their experiences about eating disorders.

The limitations of the present study include cross sectional design, convenient sampling and data were collected using self reported questionnaires including BMI was calculated by height and weight measures reported by the participants. Hence, the findings cannot be generalized to all health science students in India. Future studies with random sampling and qualitative designs could be conducted in different regions in India. Despite these limitations, the present study sample was from two universities from South India and larger sample provided interesting findings that could be helpful in planning interventional programs to prevent eating disorders in this population.

Conclusion. The findings indicate that gender differences exist in body weight perception, satisfaction, eating attitudes and weight control behaviors in Medical and nursing undergraduates. Women were more dissatisfied, perceived themselves as overweight and practiced binge eating than men. Though there were small 
Gender Differences in Body Mass Index, Body Weight Perception, weight satisfaction, disordered eating and Weight control strategies among Indian Medical and Nursing Undergraduates

differences between the genders, cannot be ignored as men agreed that they have undergone treatment for eating disorders. Further, more in depth studies are required to explore the reasons for these gender differences and to develop gender based intervention programs to prevent eating disorders in these populations.

Acknowledgements: We heart fully thank the participants for their valuable contribution.

\section{References}

1. Quick VM, Byrd-Bredbenner C. Disturbed eating behaviours and associated psychographic characteristics of college students. J Hum Nutr Diet. 2013; 26(Suppl 1):53-63.

2. Meulemans S, Pribis P, Grajales T, Krivak G. Gender Differences in Exercise Dependence and Eating Disorders in Young Adults: A Path Analysis of a Conceptual Model. Nutrients. 2014; 6(11):4895905.

3. Crow SJ, Peterson CB, Swanson SA, Raymond NC, Specker S, Eckert ED, et al. Increased mortality in bulimia nervosa and other eating disorders. Am. J. Psychiatry. 2009; 166(12):1342-6.

4. APA. Diagnostic and statistical manual of mental disorders: DSM-5. Washington, D.C: American Psychiatric Association; 2013.

5. Striegel-Moore RH, Bulik CM. Risk factors for eating disorders. Am. Psychol. 2007; 62(3):181-98.

6. Sirang Z, Bashir HH, Bilal J, Khan SH, Hussain $\mathrm{SA}$, Baig A, et al. Weight patterns and perceptions among female university students of Karachi: a cross sectional study. BMC Public Health. 2013; 13:230.

7. Matthiasdottir E, Jonsson SH, Kristjansson AL. Body weight dissatisfaction in the Icelandic adult population: a normative discontent? Eur. J.Public Health. 2012; 22(1):116-21.

8. Markham L. Current findings on males with eating disorders. Adv. Eat. Disord. 2015; 3(3):340-1.

9. Liao $\mathrm{Y}$, Liu T, Cheng $\mathrm{Y}$, Wang J, Deng $\mathrm{Y}$, Hao $W$, et al. Changes in eating attitudes, eating disorders and body weight in Chinese medical university students. Int. J. Soc. Psychiatry. 2013; 59(6):578-85.
10. Chandra PS, Abbas S, Palmer R. Are eating disorders a significant clinical issue in urban India? a survey among psychiatrists in Bangalore. Int. J. Eat. Disord. 2012; 45(3):443-6.

11. Prasad V, Kanimozhy K, Venkatachalam J, Madhanraj K, Singh Z. Body shape dissatisfaction and overweight noesis among polytechnic college students in Puducherry-A cross sectional study. 2015. Int. J. Indian Psychol. 2015; 2(4):44-52.

12. Ramaiah RR. Eating disorders among medical students of a rural teaching hospital: a crosssectional study. Int. J. Community Med. Public Health. 2015; 2(1):25-8.

13. Singh Mannat M, Parsekar SS, Bhumika T. Body Image, Eating Disorders and Role of Media among Indian Adolescents. J. Indian Assoc. Child Adolesc. Ment. Health 2016; 12(1):9-35.

14. Tremblay L, Limbos M. Body image disturbance and psychopathology in children: research evidence and implications for prevention and treatment. Curr. Psychiatry Rev. 2009; 5(1):6272.

15. Morgan JF, Reid F, Lacey JH. The SCOFF questionnaire: assessment of a new screening tool for eating disorders. BMJ. 1999; 319(7223):1467-8.

16. Berger $U$, Wick K, Holling H, Schlack R, Bormann $B$, Brix $C$, et al. Screening of disordered eating in 12-Year-old girls and boys: psychometric analysis of the German versions of SCOFF and EAT-26 Psychother Psychosom Med Psychol. 2011; 61(7):311-8

17. Garner DM, Olmsted MP, Bohr Y, Garfinkel PE. The eating attitudes test: psychometric features and clinical correlates. Psychol. Med. 1982; 12(4):871-8.

18. Mak K-K, Lai C-M. Assessment of Dietary Restraint: Psychometric Properties of the Revised Restraint Scale in Hong Kong Adolescents. Int. J Behav. Med. 2012;19(2):199-207.

19. Spitzer RL, Kroenke K, Williams JB. Validation and utility of a self-report version of PRIME-MD: The PHQ primary care study. Primary Care Evaluation of Mental Disorders. Patient Health Questionnaire. JAMA. 1999; 282(18):1737-44.

20. Forrester-Knauss C, Zemp Stutz E. Gender differences in disordered eating and weight dissatisfaction in Swiss adults: Which factors matter? BMC Public Health. 2012;12(1):1-9. 
21. Kuan PX, Ho HL, Shuhaili MS, Siti AA, Gudum HR. Gender differences in body mass index, body weight perception and weight loss strategies among undergraduates in Universiti Malaysia Sarawak. Malays J. Nutr. 2011;17(1):67-75.

22. Yost J, Krainovich-Miller B, Budin W N, R. Assessing weight perception accuracy to promote weight loss among U.S. female adolescents: a secondary analysis. BMC Public Health. 2010;9(10):465.

23. Lee J, Lee Y. The association of body image distortion with weight control behaviors, diet behaviors, physical activity, sadness, and suicidal ideation among Korean high school students: a cross-sectional study. BMC Public Health. 2015;16:39.

24. Ojala K VC, Välimaa R, Currie C, Villberg J, Tynjälä $\mathrm{J}$, Kannas L. Attempts to lose weight among overweight and non-overweight adolescents: a cross-national survey. Int. J. Behav. Nutr. Phys. Act. 2007;14(4):50.

25. Millstein RA, Carlson SA, Fulton JE, Galuska DA, Zhang J, Blanck HM, et al. Relationships Between
Body Size Satisfaction and Weight Control Practices Among US Adults. Medscape J. Med. 2008;10(5):119.

26. Memon AA AS-R, Siddiqui EU, Naeem SS, Ali SA, Mehmood K. Eating disorders in medical students of Karachi, Pakistan-a cross-sectional study. BMC Res. Notes. 2012; 5:84.

27. Lipson SK, Sonneville KR. Eating disorder symptoms among undergraduate and graduate students at 12 U.S. colleges and universities. Eat. Behav. 2017; 24:81-8.

28. Striegel-Moore RH, Rosselli F, Perrin N, DeBar L, Wilson GT, May A, et al. Gender difference in the prevalence of eating disorder symptoms. Int. J. Eat. Disord. 2009; 42(5):471-4.

29. Tsai SA, Lv N, Xiao L, Ma J. Gender Differences in Weight-Related Attitudes and Behaviors Among Overweight and Obese Adults in the United States. Am. J. Mens. Health. 2016; 10(5):389-98.

30. Stewart M-C, Keel PK, Schiavo RS. Stigmatization of anorexia nervosa. Int. J. Eat. Disord. 2006; 39(4):320-5. 